\title{
Application of key ecological attributes to assess early restoration of river floodplain habitats: a case study
}

\author{
A. Maria Lemke $\cdot$ James R. Herkert $\cdot$ Jeffery W. Walk $\cdot$ K. Douglas Blodgett
}

Received: 22 February 2017/Revised: 31 May 2017/ Accepted: 7 June 2017/Published online: 21 June 2017

(C) The Author(s) 2017. This article is an open access publication

\begin{abstract}
The Nature Conservancy acquired the Emiquon Preserve along the Illinois River, Illinois, with the primary objective of restoring ecological floodplain processes and habitats that promote and sustain native species and communities. The Conservancy convened an Emiquon Science Advisory Council prior to restoration implementation that identified key ecological attributes (KEAs) for riverine and backwater targets, KEA indicators, and acceptable ranges for those indicators. We assessed the application of this methodology to evaluate status of conservation targets and to inform future science and management at Emiquon. The KEA framework provided an important function of directing a systematic monitoring program that provided fundamental data on changing environmental conditions that were
\end{abstract}

Guest editors: Michael J. Lemke, A. Maria Lemke \& Jeffery W. Walk / Large-Scale Floodplain Restoration in the Illinois River Valley

A. M. Lemke $(\varangle) \cdot$ K. D. Blodgett

The Nature Conservancy, 11304 N Prairie Road, Lewistown, IL 61542, USA

e-mail: mlemke@tnc.org

J. R. Herkert

Illinois Audubon Society, 2315 Clear Lake Avenue, Springfield, IL 62703, USA

J. W. Walk

The Nature Conservancy, 240 SW Jefferson St., Suite

301, Peoria, IL 61602, USA incorporated into annual target evaluations. Data show that $46-55 \%$ of all indicators were within acceptable ranges prior to reconnection of the preserve with the Illinois River. Recent completion of a water control structure represents a critical intervention that provides potential to improve conservation status of those floodplain and riverine targets that depend on water management and river connectivity. Continued review and modification of the KEA model in conjunction with a strategic monitoring program will provide critical information to guide relevant management decisions and testable hypotheses to reduce potential threats and achieve future restoration goals.

Keywords Key ecological attributes - Emiquon preserve · Illinois River · Floodplain restoration . Biological assessment

\section{Introduction}

Ecological structure and function of large river systems are increasingly threatened worldwide as modifications for utilitarian purposes such as navigation, hydroelectric power, agricultural production, and flood control intensify. Fragmentation of river channels by navigation dams and reduced hydrologic connectivity between floodplains and the main river channel due to levees are two primary impacts that threaten ecological integrity of these working rivers 
(e.g., Dynesius \& Nilsson, 1994; Gore \& Shields, 1995; Lamouroux et al., 2015). Hydrologic alteration and habitat degradation accompanying this infrastructure are two major drivers that have placed riverine floodplains among the most globally endangered ecosystems such that up to $90 \%$ of floodplains in Europe and North America have lost many of their natural ecological functions (Sparks, 1995; Tockner \& Stanford, 2002). Increased efforts to conserve and restore floodplain rivers have paralleled a rising global awareness of the importance of these ecosystems for biodiversity and the environmental services they provide.

The Mississippi River watershed in the United States is the fourth largest in the world, providing critical habitat that supports incredible biological diversity for resident and migratory aquatic and terrestrial species (Page \& Burr, 1991; UMRCC, 2000; Weitzell et al., 2003). Although $90 \%$ of the Lower Mississippi River has been leveed and drained primarily for agricultural production, an estimated $50 \%$ of the original floodplain remains hydrologically connected to the main channel of the Upper Mississippi River (UMR) and retains seasonal flood-pulsed events (Sparks et al., 1998). The Illinois River is one of the major tributaries to the UMR, draining $44 \%$ of the state of Illinois and linking the Great Lakes to the Gulf of Mexico. Glacial activity and subsequent flood events created an extensive floodplain in the Illinois River basin relative to the size of the river channel, approximately $50 \%$ of which remains unleveed from the main channel (Sparks, 1995; Mettler-Cherry \& Smith, 2009). A study conducted by the National Research Council (NRC, 1992) recommended the Upper Mississippi and Illinois rivers as two of the three large, river-floodplain systems remaining in the U.S. that were priorities for restoration. Several successive reports by the UMR Conservation Committee (2000) and the U.S. Army Corps of Engineers (2007) supported NRC (1992) conclusions regarding the importance of restoring floodplain function to ensure the ecological integrity of these river systems.

Development of an operational framework that coordinates such recommendations with science and management is integral to comprehensive planning, implementation, and assessment of restoration projects (Rogers, 2006; Roux et al., 2006). As such, frameworks have been developed for large river restoration projects that link strategic management with monitoring and hypothesis testing (Koebel 1995; Rogers \& Biggs, 1999; Davies et al., 2010; Lamouroux et al., 2015), and empirical research that measures effectiveness of restoration strategies continues to increase (Wortley et al., 2013; Palmer et al., 2014). Monitoring programs are integral to these frameworks by providing pivotal data that inform the restoration assessments that are subsequently integrated into management decisions. To accurately assess the effectiveness of restoration programs, it is imperative that monitoring efforts focus on clearly defined criteria or targets that represent the processes, species, and communities that are indicative of the ecological integrity of the system (Jungwirth et al., 2002; Wortley et al., 2013). This can be a challenge.

In this case study, we used key ecological attribute (KEA) measures for conservation targets (Parrish et al., 2003) to assess ongoing restoration efforts of the Emiquon Preserve's 2550-ha floodplain complex along the Illinois River. Primary data for fish, aquatic vegetation, and waterfowl that were incorporated into KEA assessments are published in this special issue (Hagy et al., 2016; Hine et al., 2016; VanMiddlesworth et al., 2016). We evaluated the collective data for these conservation targets within the KEA framework to provide a comprehensive assessment of the Preserve status during the first 8 years of restoration prior to reconnection with the river. This paper does not focus on the process of KEA development, which is well described by Parrish et al. (2003), but on the application of this approach to assess conservation status and to inform future management and science decisions at the Preserve that may be relevant to similar floodplain restoration projects.

\section{Background}

The Nature Conservancy (hereafter, the Conservancy) acquired the Preserve in 2000 with the primary objective of restoring ecological floodplain processes and habitats that promote and sustain native species and communities (TNC, 2000). Prior to isolation from the river, this site comprised two backwater lakes that were intensively studied by aquatic scientists (Hart, 1896; Hempel, 1898; Kofoid, 1903; Forbes \& Richardson, 1913) and well known as one of the most highly productive fish and waterfowl habitats along the Illinois River (Havera et al., 2003). Following 
extensive levee construction throughout the basin in the 1920s, the lakes were drained for agricultural purposes. Restoration began in 2007 as hydraulic pumping that had maintained dry soil conditions for farming was discontinued, allowing reinundation of the historical floodplain habitat primarily from precipitation. With the completion of a water control structure in 2016, we are now beginning the second stage of restoration that includes a managed reconnection of the Preserve to the Illinois River.

The Conservancy's Emiquon Preserve is located within the LaGrange Reach of the Illinois River (centroid: N4471044, E749023 UTM Z15), adjacent to U.S. Fish and Wildlife Service's Emiquon National Wildlife Refuge (1052 ha) and Chautauqua National Wildlife Refuge (1817 ha). Collectively, these sites comprise the 5729-ha Emiquon Complex of interconnected rivers, sloughs, flood-pulsed backwater lakes and wetlands, bottomland hardwood forests, prairies, and riverine bluff habitat that represent the historically diverse habitats of the Illinois River floodplain system. In 2012, the Emiquon Complex was designated under the Ramsar Convention as a Wetland of International Importance, meeting or exceeding eight of the nine criteria required for validation of global importance (Ramsar, 2014). The complex provides habitat for many rare and federally or state threatened and endangered species and contributes to a corridor for migratory Neotropical song birds, waterfowl, and fishes such as paddlefish (Polyodon spatula) and American eel (Anguilla rostrata).

Wetted area at the Preserve increased rapidly from 252 to 1062 ha between 2007 and 2008, and has remained between 1782 and 1944 ha since 2009 (Hine et al., 2016). Aquatic plants established quickly without human intervention and have been monitored by researchers from the Illinois Natural History Survey's (INHS) Illinois River and Forbes Biological Stations since 2007 (Hine et al., 2016). Over 1.2 million larval and 600 adult largemouth bass ( $M i$ cropterus salmoides) were introduced in 2007, and an additional 435,000 young-of-year and brood stock of 30 native fish species were stocked between 2007 and 2010 (VanMiddlesworth et al., 2016).

Record flooding in spring of 2013 resulted in the overflow of Illinois River water across approximately $500 \mathrm{~m}$ of the levees for 6 days. Aging infrastructure of the drainage pump system prior to the flood, and subsequent removal of the pumps during the flood, has limited the Conservancy's ability to manage water levels in the Preserve. However, the completion of a gated structure between the Preserve and the river in 2016 will allow passage for riverine fishes, nutrients, and plankton and provide future water management capacity to lower water levels for moist soil plant production, sediment consolidation, and other management requirements.

Early planning and development of key ecological attributes

The Conservancy convened an Emiquon Science Advisory Council (Council) from 2001 to 2004 to provide input and guidance for restoration and management planning that included scientists, land managers, and taxonomic experts from 26 colleges, universities, state and federal agencies, and non-profit organizations (TNC, 2006). Council directives were to (1) identify and evaluate ways to address potential impediments to successful restoration, (2) evaluate options and next steps for achieving ecological goals for the site, and (3) establish a framework for information and data gathering. Early in the process, the council determined that site-specific models were needed to assess potential effects of management options (i.e., full, partial, and no connection to the river) on key ecological processes and conservation targets. Subsequently, the Illinois State Water Survey developed a hydrologic model described by Sparks et al. (2016) to assess likely sediment accumulation at Emiquon from riverine inputs (Demissie et al., 2005), and the University of Illinois developed a model to simulate the responses of moist soil vegetation to water level management (Ahn et al., 2004).

A Measures of Success framework was introduced as a methodology to identify potential effects of management options on conservation targets and to annually assess restoration status at the Preserve (Parrish et al., 2003). This four-step process identifies (1) conservation targets, (2) KEAs for those targets, (3) acceptable ranges of variation for each KEA, and (4) target status based on whether KEAs are within acceptable ranges. Emiquon plant and animal targets (Table 1) were identified as a subset of conservation targets previously determined for the Illinois River during the development of the Illinois River Site Conservation Plan (TNC, 1998). The Council identified $26 \mathrm{KEAs}$ and 60 indicators with indicator ranges 
Table 1 Overview version of key ecological attributes (KEAs), indicators for each KEA, and desired ranges for each indicator used to assess restoration status for plant and animal and plant conservation targets at the Emiquon Preserve in Illinois

\begin{tabular}{|c|c|c|c|}
\hline Target & KEA & Indicator & Desired range \\
\hline \multirow[t]{6}{*}{ Moist soil vegetation } & \multirow[t]{5}{*}{$\begin{array}{l}\text { Community } \\
\text { composition }\end{array}$} & $\begin{array}{l}\text { Native versus exotic } \\
\text { species }\end{array}$ & $<10 \%$ exotics \\
\hline & & $\begin{array}{l}\text { Native versus exotic } \\
\text { species }\end{array}$ & $100 \%$ suppression of purple loosestrife $\mathrm{i}^{\mathrm{i}}$ and common reed \\
\hline & & Non-woody invasives & $<50 \%$ non-woody invasives* \\
\hline & & Woody encroachment & $<10 \%$ coverage $*$ \\
\hline & & Forb and grass coverage & Forbs at least $10 \%$ coverage compared to grasses \\
\hline & $\begin{array}{l}\text { Disturbance } \\
\text { (fire) regime }\end{array}$ & $\begin{array}{l}\text { Fire return interval and } \\
\text { seasonality }\end{array}$ & $\begin{array}{l}\text { Fire return interval of } 3-5 \text { years and vary seasons from spring } \\
\text { to fall }\end{array}$ \\
\hline \multirow[t]{2}{*}{ Wading birds } & Feeding & Feeding habitat & Shallow water $(<0.5 \mathrm{~m})$ with abundant fish \\
\hline & $\begin{array}{l}\text { Nesting and } \\
\text { reproduction }\end{array}$ & Nesting habitat & Undisturbed mature bottomland forest and shrubs \\
\hline \multirow[t]{2}{*}{ Shorebirds } & \multirow[t]{2}{*}{ Feeding } & Foraging habitat & Shallow wet areas $(0-5 \mathrm{~cm})$ with some mud flats \\
\hline & & $\begin{array}{l}\text { Timing and availability of } \\
\text { mud flats }\end{array}$ & Area dewatered and $<5 \mathrm{~cm}$ deep July-August \\
\hline \multirow[t]{2}{*}{ Other breeding birds } & \multirow[t]{2}{*}{$\begin{array}{l}\text { Nesting and } \\
\text { feeding }\end{array}$} & Nesting habitat & Emergent vegetation interspersed with shallow open water \\
\hline & & Brood species richness & Confirmed nesting of $\geq 3$ species* \\
\hline \multirow[t]{3}{*}{$\begin{array}{l}\text { Submersed aquatic } \\
\text { vegetation }\end{array}$} & $\begin{array}{l}\text { Underwater } \\
\text { irradiance }\end{array}$ & Secchi disk measure & $\begin{array}{l}\text { No less than half maximum water depth in areas } \leq 1.5 \mathrm{~m} \text { late } \\
\text { spring-early summer }\end{array}$ \\
\hline & Hydrology & Water depth & $\begin{array}{l}\text { Rate of water rise not to exceed } 1.5 \mathrm{~cm}^{-1 a y}{ }^{-1} \text { during growing } \\
\text { season }{ }^{\mathrm{a}} \text {; water fluctuations do not exceed } 1 \mathrm{~m} *\end{array}$ \\
\hline & $\begin{array}{l}\text { Community } \\
\text { composition }\end{array}$ & $\begin{array}{l}\% \text { Natives versus exotic } \\
\text { species }\end{array}$ & $<10 \%$ exotics \\
\hline \multirow{4}{*}{$\begin{array}{l}\text { Emergent and } \\
\text { floating-leaved } \\
\text { vegetation }\end{array}$} & Hydrology & Stable water depth & $\begin{array}{l}\text { Rate of water rise does not exceed } 1.5 \mathrm{~cm} \mathrm{day}^{-1} \text { during } \\
\text { growing season }{ }^{\mathrm{a}} \text {; water fluctuations do not exceed } 1 \mathrm{~m}^{*}\end{array}$ \\
\hline & \multirow[t]{3}{*}{$\begin{array}{l}\text { Community } \\
\text { composition }\end{array}$} & $\begin{array}{l}\text { Native versus exotic } \\
\text { species }\end{array}$ & No less than $90 \%$ dominance by native species \\
\hline & & $\begin{array}{l}\text { Cattail, river bulrush }{ }^{\mathrm{b}} \text {, } \\
\text { common reed }^{\mathrm{c}} \\
\text { dominance }\end{array}$ & $\begin{array}{l}\text { Hemi-marsh on } 10-15 \% \text { of wetland area (assessed from aerial } \\
\text { imagery) }\end{array}$ \\
\hline & & $\begin{array}{l}\text { Cattail, river bulrush, } \\
\text { common reed } \\
\text { dominance }\end{array}$ & $\begin{array}{l}\text { One species representing no more than } 50 \% \text { of plant } \\
\text { community (assessed from ground transects) }\end{array}$ \\
\hline \multirow{8}{*}{$\begin{array}{l}\text { Riverine and } \\
\text { backwater fishes }\end{array}$} & \multirow[t]{2}{*}{ Assemblage } & \# native species & $\geq 25$ species \\
\hline & & Native species & $>50 \%$ of total biomass \\
\hline & $\begin{array}{l}\text { Community } \\
\text { composition }\end{array}$ & Native predatory fish & $\geq 50 \mathrm{~h}^{-1}$ catch of largemouth bass + bowfin $^{\mathrm{d}}$ \\
\hline & \multirow[t]{3}{*}{ Spawning } & Dissolved oxygen & 4 ppm \\
\hline & & $\begin{array}{l}\text { Substrate variability/ } \\
\text { structure }\end{array}$ & $\begin{array}{l}\text { Diverse shoreline, shade, woody debris, open areas, } \\
\text { submerged plants }\end{array}$ \\
\hline & & $\begin{array}{l}\text { Frequency of connection } \\
\text { to Illinois River }\end{array}$ & $\begin{array}{l}\text { Every } 3 \text { years for long-lived species; more frequently for } \\
\text { short-lived species }\end{array}$ \\
\hline & \multirow[t]{2}{*}{ Nursery } & $\begin{array}{l}\text { Accessibility for riverine } \\
\text { fish }\end{array}$ & $\begin{array}{l}\text { Presence of young-of-year freshwater drum }{ }^{\mathrm{e}}, \text { Goldeye }^{\mathrm{f}} \text {, } \\
\text { bigmouth buffalo }^{\mathrm{g}}\end{array}$ \\
\hline & & Native fish larvae & Dominance of native species \\
\hline
\end{tabular}


Table 1 continued

\begin{tabular}{|c|c|c|c|}
\hline Target & KEA & Indicator & Desired range \\
\hline & Feeding & Adult condition & Relative weights $>90$ \\
\hline & & $\begin{array}{l}\text { Aquatic vegetation and } \\
\text { epifauna }\end{array}$ & $25-40 \%$ vegetated littoral with epifauna July and August \\
\hline & & $\begin{array}{l}\text { Secondary production } \\
\text { delivered to the river }\end{array}$ & No defined indicator ranges \\
\hline & $\begin{array}{l}\text { Over- } \\
\text { wintering }\end{array}$ & $\begin{array}{l}\text { Presence of backwater } \\
\text { species }\end{array}$ & Water temperature at least $1^{\circ} \mathrm{C}$ at $2 \mathrm{~m}$ \\
\hline & & $\begin{array}{l}\% \text { of deep, oxygenated } \\
\text { water }\end{array}$ & $5 \%>3 \mathrm{~m} ; 10 \% 2-3 \mathrm{~m} ; 25 \% 1-2 \mathrm{~m} ; 60 \%<1 \mathrm{~m} ; 4-6 \mathrm{ppm}$ \\
\hline & & $\begin{array}{l}\text { Concentrations of over- } \\
\text { wintering native species }\end{array}$ & No defined indicator ranges \\
\hline \multirow[t]{5}{*}{ Waterfowl } & $\begin{array}{l}\text { Nesting and } \\
\text { reproduction }\end{array}$ & Availability of cavities & 1 per acre \\
\hline & & Brood counts & 15 broods per $\mathrm{km}^{2}$ \\
\hline & & Ground nesting habitat & $\begin{array}{l}\text { Minimum of } 200 \mathrm{~m} \text { of permanent grass cover within } 400 \mathrm{~m} \text { of } \\
\text { water edge }\end{array}$ \\
\hline & & Brood habitat & Diversity of wetland habitats \\
\hline & & Food base & Presence of epiphytic invertebrates \\
\hline \multirow{6}{*}{$\begin{array}{l}\text { Waterfowl dabblers } \\
\text { (Fall) }\end{array}$} & Feeding & Feeding habitat & Fall inundation area $\geq 50 \%$ of pre-summer drawdown levels \\
\hline & & Moist soil seed production & $\geq 578 \mathrm{~kg} \mathrm{ha}^{-1}$ \\
\hline & & $\begin{array}{l}\text { Moist soil energetic } \\
\text { carrying capacity }\end{array}$ & 1 million duck energetic days (DEDs) from moist soil* \\
\hline & & $\begin{array}{l}\text { Overall energetic carrying } \\
\text { capacity }\end{array}$ & 3.5 million DEDs from all habitats* \\
\hline & $\begin{array}{l}\text { Feeding/ } \\
\text { disturbance }\end{array}$ & Total non-mallard DUDs & $\geq 783$ DUDs ha ${ }^{-1} *$ \\
\hline & & $\begin{array}{l}\text { Relative non-mallard } \\
\text { DUDs }\end{array}$ & $>$ average DUDs ha ${ }^{-1}$ from top IRV lakes* \\
\hline \multirow[t]{3}{*}{$\begin{array}{l}\text { Waterfowl divers } \\
\text { (Fall) }\end{array}$} & Feeding & Feeding habitat & $\begin{array}{l}\text { Water depth of } 1-5 \mathrm{~m} \text { and }<10 \% \text { coverage of emergent } \\
\text { vegetation }\end{array}$ \\
\hline & $\begin{array}{l}\text { Feeding/ } \\
\text { Disturbance }\end{array}$ & Total diving DUDs & $>189 \mathrm{ha}^{-1 *}$ \\
\hline & & Relative DUDs & $>$ average DUDs ha ${ }^{-1}$ from top IRV lakes* \\
\hline (Spring) & & Total diving DUDs & $>405 \mathrm{ha}^{-1 *}$ \\
\hline \multirow[t]{3}{*}{$\begin{array}{l}\text { Waterfowl divers and } \\
\text { dabblers (Fall) }\end{array}$} & $\begin{array}{l}\text { Feeding/ } \\
\text { disturbance }\end{array}$ & Total DUDs & $\geq 1500$ DUDs ha $^{-1}$ \\
\hline & & Relative DUDs & $>$ average DUDs ha ${ }^{-1}$ from top IRV lakes* \\
\hline & Disturbance & $\begin{array}{l}\text { Distance from human } \\
\text { activity }\end{array}$ & $\geq 400 \mathrm{~m}$ distance from human activity with some cover \\
\hline \multirow[t]{4}{*}{ (Spring) } & Feeding & Feeding habitat & $\begin{array}{l}\text { Shallow flooded areas }(<50 \mathrm{~cm}) \text { over residual vegetation and } \\
\text { presence of invertebrates }\end{array}$ \\
\hline & Disturbance & $\begin{array}{l}\text { Distance from human } \\
\text { activity }\end{array}$ & Minimum distance of $200 \mathrm{~m}$ \\
\hline & & $\begin{array}{l}\text { American coot brood } \\
\text { density }\end{array}$ & $>1$ brood per $\mathrm{km}^{2} *$ \\
\hline & Disturbance & $\begin{array}{l}\text { Amount of undisturbed } \\
\text { area }\end{array}$ & Significant size areas that lack major disturbance \\
\hline
\end{tabular}


Table 1 continued

\begin{tabular}{|c|c|c|c|}
\hline Target & KEA & Indicator & Desired range \\
\hline \multirow[t]{2}{*}{ Floodplain forest } & $\begin{array}{l}\text { Community } \\
\text { composition }\end{array}$ & $\%$ soft mast & Floodplain forest community $\leq 25 \%$ soft mass species \\
\hline & Hydrology & Pecan recruitment ${ }^{\mathrm{h}}$ & No water on forested areas April-August 9 of 10 years \\
\hline Canopy cover & $\begin{array}{l}\text { \% canopy } \\
\text { cover }\end{array}$ & $75 \%$ or more canopy cover & \\
\hline \multirow[t]{2}{*}{ Boltonia decurrens } & Hydrology & $\begin{array}{l}\text { Frequency/duration of } \\
\text { flooding }\end{array}$ & $\begin{array}{l}\text { Land dewatered by June } 15 \text { and inundated }>3 \text { months (April- } \\
\text { Sept.) in } 1 \text { of } 3 \text { years }\end{array}$ \\
\hline & & Timing of recession & Late winter/early spring; conclude no later than June 15 \\
\hline \multirow[t]{3}{*}{ Backwater mussels } & Feeding & Fine particulate matter & Cyanobacteria $<100 \mathrm{ml}^{-1}$ \\
\hline & Reproduction & Reproductive success & Presence of juvenile mussels $\geq 1 \%$ of population \\
\hline & $\begin{array}{l}\text { Community } \\
\text { composition }\end{array}$ & $\begin{array}{l}\text { Number of representative } \\
\text { species }\end{array}$ & $\geq 4$ species present \\
\hline
\end{tabular}

Indicators designated with * were added as new measures during a 2012 revision, and italicized text refers to indicators that were refined
${ }^{\text {a }}$ May-September
b Scirpus fluviatilis
c Phragmites australis
d Amia calva
e Aplodinotus grunniens
f Hiodon alosoides
g Ictiobus cyprinellus
h Carya illinoinensis
i Lythrum salicaria

for 11 Emiquon conservation targets using expert input and published literature (Table 1; TNC, 2006). As possible, KEAs included aspects of biological composition, interactions and processes, and environmental conditions necessary to sustain the target's natural dynamics, whereas indicators and indicator ranges provided specific information that could be measured to detect changes in KEA status (Noss, 1990; Dale \& Beyeler, 2001; Parrish et al., 2003). Desired indicator ranges incorporated natural ranges of variation necessary to ensure long-term persistence of the target, integrity of the area's biological diversity, and species' evolutionary potential (Christensen et al., 1996; Holling \& Meffe, 1996; Poff et al., 1997). Subsequent refinement of the KEAs, indicators, and ranges were conducted between 2004 and 2005 using published literature, continued input from scientific experts, and final review by the Council (TNC, 2006).
Emiquon KEAs were updated in 2012 to clarify and further quantify specific indicator ranges and to assess the practicality and utility of each attribute in the context of new water level management capacity (Table 1). Several indicator ranges were originally described qualitatively, thus were problematic for setting quantifiable restoration goals. Other indicator ranges were refined or added as potential important indicators of system condition using updated data from Emiquon and long-term Illinois River monitoring. Several indicators were initially associated with multiple measures that made a single rating for that indicator challenging. Additionally, methodologies initially identified to measure some indicators had proven ineffective or impractical at delivering the intended information. Conservancy science staff moderated the revision process with review by scientists from INHS's Illinois River and Forbes Biological 
Stations and the Conservancy's Illinois Science Advisory Committee.

\section{Monitoring}

Intensive monitoring of KEA indicators began in 2008 and has since been conducted by researchers from the INHS's Forbes Biological Station for waterfowl, shorebirds, and wetland vegetation, and Illinois River Biological Station (IRBS) for fish and aquatic vegetation. Waterbird brood surveys were conducted in late spring and summer, and weekly ground surveys were conducted during fall and spring migrations and converted to duck use days (DUDs) as described by Hagy et al. (2016). Aerial surveys were conducted in the fall in conjunction with INHS's waterfowl inventory program that provided information on waterfowl use days at the Preserve relative to the larger Illinois River Valley (Hagy et al., 2016). Forbes researchers have used aerial imagery and ground transects to map and quantify vegetation community types across the Preserve since 2007 (Hine et al., 2016).

Monitoring protocols used by IRBS at the Preserve followed standardized Long Term Resource Monitoring Program methods developed by the U.S. Geological Survey for fishes, water quality, and vegetation of the Upper Mississippi and Illinois River watersheds (USGS, 2015; VanMiddlesworth et al., 2016). Using these protocols ensured that data from the Emiquon Preserve could be referenced within larger context of these river systems. No data for mussel indicators were collected during the study period. Monitoring methods and research results were documented in annual reports (e.g., Hine et al., 2014; VanMiddlesworth et al., 2014), in which KEA indicators were classified as either "within acceptable ranges", "not in range", or "no available data", and recorded in an internal database that includes related metadata. Water levels at the Preserve have been recorded by the Conservancy using staff gauge readings from 2003 to the present day. On average, staff gauge readings are collected weekly during the winter (November-February) and two to three times a week from March through October. Additional monitoring for aquatic invertebrates, water quality, hydrology, and microbial communities has been conducted by Conservancy staff and researchers from the University of Illinois Springfield.

\section{Assessment of restoration status}

Site level

Parrish et al. (2003) stated that an overall rating for a site can be obtained by combining indicator ratings for all targets, and that the site is considered conserved when all ratings for the conservation targets are within acceptable ranges of variation. Although not all indicators could be monitored at the Emiquon Preserve during the first 8 years of restoration, data from the $68-75 \%$ of indicators that were monitored across all years showed that $46-55 \%$ of all indicators were within acceptable ranges (Table 2). These assessments suggest that restoration at Emiquon is providing benefits to riverine floodplain targets but that there are important aspects that still need improvement. These results are not surprising given the short time since restoration began and the lack of water management capacity during this time. A large proportion of the indicators that were not monitored are dependent on water level management and are not expected to change until the Conservancy begins to manage hydrology; such indicators include seasonal waterbird feeding habitats (e.g., mudflats), bottomland forest recruitment, and Boltonia decurrens establishment (Table 1). In addition, several other indicators are long-term measures related to bottomland forest restoration that will take years to decades to mature and reach the defined acceptable ranges. Based on these differences in time and scale to attain conservation status among the 62 indicators, combined with the inability to manage water levels, we would not expect all measures to be in desired ranges in the short time frame of 8 years.

\section{Target level}

\section{Moist soil and waterbirds}

For any single target to be considered conserved, all attributes for that target must fall within acceptable ranges of variation (Parrish et al., 2003). Only moist soil vegetation met this requirement during 2013 when the final indicator related to the percentage of forbs to grasses was measured and shown to be within acceptable range (Fig. 1A). Waterbirds showed the lowest percentage of indicators that reached acceptable ranges (Fig. 1B), related to a lack of mature 
Table 2 Number and percent (\%) of total indicators measured from 2008 through 2014, indicators that were in acceptable ranges, and indicators that were not in acceptable ranges defined by the key ecological attribute framework for the Emiquon Preserve

\begin{tabular}{lllc}
\hline Year & Number $(\%)$ of indicators measured & Number $(\%)$ of indicators in range & Number $(\%)$ of indicators not in range \\
\hline 2008 & $43(72)$ & $33(55)$ & $10(17)$ \\
2009 & $41(68)$ & $32(53)$ & $9(15)$ \\
2010 & $41(68)$ & $28(47)$ & $13(22)$ \\
2011 & $44(73)$ & $31(52)$ & $13(22)$ \\
2012 & $42(69)$ & $28(46)$ & $14(23)$ \\
2013 & $45(74)$ & $32(52)$ & $13(21)$ \\
2014 & $47(75)$ & $31(49)$ & $16(25)$ \\
Mean & $43(71)$ & $31(51)$ & $13(21)$ \\
\pm 1 SE & $0.8(1.0)$ & $0.7(1.3)$ & $0.9(1.4)$ \\
\hline
\end{tabular}

Total number of indicators ranged from 60 indicators (2008-2011), 61 indicators (2012 and 2013), and 63 indicators in 2014

bottomland forest nesting sites and the inability to manage water levels to create waterbird feeding habitats (Fig. 2A). However, there were several indicators that could still be estimated from aerial maps and GIS related to shallow water habitat (feeding) and emergent vegetation (nesting) that may be used to better understand early restoration status of this conservation target.

\section{Fishes}

Fish targets came close to reaching conserved status by 2013 as the majority of spawning and nursery habitat indicators and water quality parameters reached environmental ranges that were identified as necessary to sustain a diverse and healthy backwater fish community (Fig. 1C). Improved conservation status over time was substantiated by healthy adult conditions (i.e., relative weights), a dominance of native young-of-year (YOY) backwater species relative to non-native species, and an increase from 7 to 20 native adult species collected annually since 2007 (VanMiddlesworth et al., 2014, 2016). Riverine YOY and adult species were not collected at the site until after the 2013 flood when Illinois River water flowed into the backwater lake (VanMiddlesworth \& Casper, 2014, 2015; VanMiddlesworth et al., 2014). Flooding introduced riverine fishes to Emiquon, providing access to vegetated spawning and nursery habitat that has been extremely limited for these species since levee construction disconnected backwaters from the river channel in the early 1920s (Thompson, 2002).
Access to these habitats improved conservation status for riverine fishes as defined by the Emiquon KEAs and emphasizes the importance of connectivity between the river and restored floodplain habitats to riverine fish targets. Future management of river connectivity will also allow export of primary and secondary production from Emiquon to the river and, in doing so, will address additional indicators that are important for improving conservation status of riverine and backwater fishes (Table 1).

\section{Aquatic vegetation}

Conservation status of submersed and emergent aquatic vegetation varied considerably over time, ultimately showing an overall decline in the number of indicators that were within the desired ranges (Fig. 1D). A distinct occurrence between 2009 and 2010 showed a decline of indicators that were in the range from 83 to $17 \%$, mostly related to changes in water transparency and depth, exotic plant species, and taxonomic evenness (Fig. 2C). Water clarity at Emiquon shifted dramatically in 2010 as Secchi transparencies declined from an average depth of $1.18 \pm 0.04 \mathrm{~m}$ early in the restoration to an average depth of $0.43 \pm 0.01 \mathrm{~m}$ between mid-2010 and 2014 (Fig. 3A). Indicator ranges accurately reflected this lake-wide shift, possibly related to a change in trophic state that could have detrimental effects on aquatic vegetation targets (Sparks et al., 2016). Lake-scale measures were representative of habitat conditions for aquatic vegetation during the early years of restoration 
Fig. 1 Total number of KEA indicators that were in acceptable ranges for A moist soil vegetation, $\mathbf{B}$ waterbirds, $\mathbf{C}$ riverine and backwater fishes, $\mathbf{D}$ aquatic vegetation, and $\mathbf{E}$ waterfowl target key ecological attributes (KEAs) from 2008 to 2014. Also shown in parentheses are the percentage of total indicators that were in range in any given year for each conservation target. Acceptable indicator ranges were identified during the development process of the KEA framework for the Emiquon Preserve, Illinois, USA
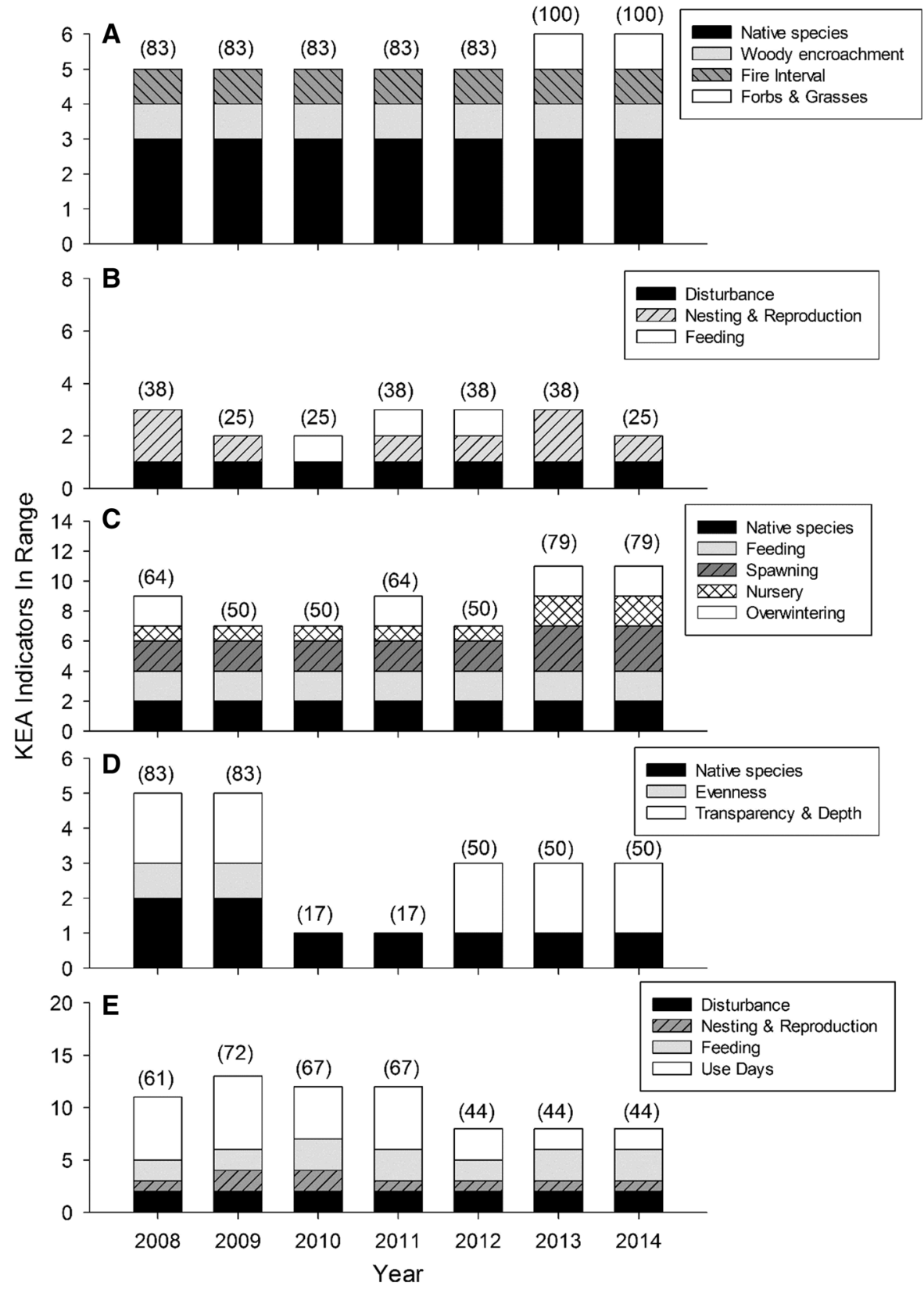

when water levels were low and transparencies were high; however, a transition period occurred as increasing water volume created a wider range of lake depths with distinct littoral and open water zones. Indicators were refined in 2012 to reflect these changes and provide measures specific to the littoral zone. Based on revised indicator ranges, Secchi transparency and water level fluctuation measures were within acceptable range status in the littoral zone for submersed and emergent vegetation in 2012-2014. In contrast, nonnative species continued to negatively influence aquatic vegetation indicator ratings. Exotic and invasive species such as curly-leaf pondweed (Potamogeton crispus) and Eurasian watermilfoil (Myriophyllum spicatum) were present in low abundances within the first year of restoration (Michaels \& Sass, 2009), and watermilfoil increased rapidly as relative biomass increased from $1.3 \%$ of the total submersed vegetation 
Fig. 2 Total number of KEA indicators that were not within acceptable ranges for $\mathbf{A}$ waterbirds, $\mathbf{B}$ riverine and backwater fishes,

$\mathbf{C}$ aquatic vegetation, and D waterfowl target key ecological attributes (KEAs) from 2008 to 2014. Also shown in parentheses are the percentage of total indicators that were not in range in any given year for each conservation target. Acceptable indicator ranges were identified during the development process of the KEA framework for the Emiquon Preserve, Illinois, USA

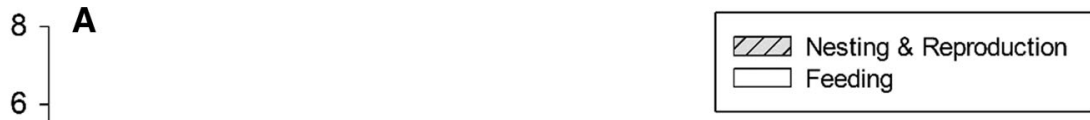

(38)

(38) (25) (25) (38)

(25) (25)
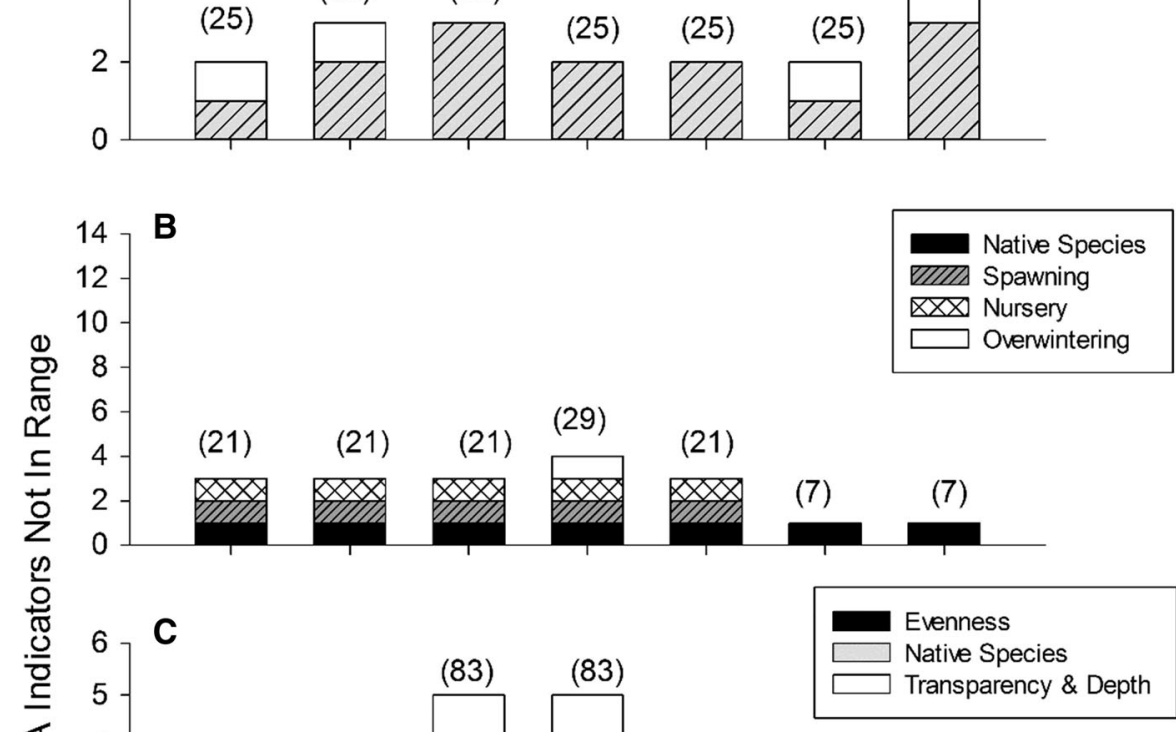

(50) (50) (50)

(17)

(17)
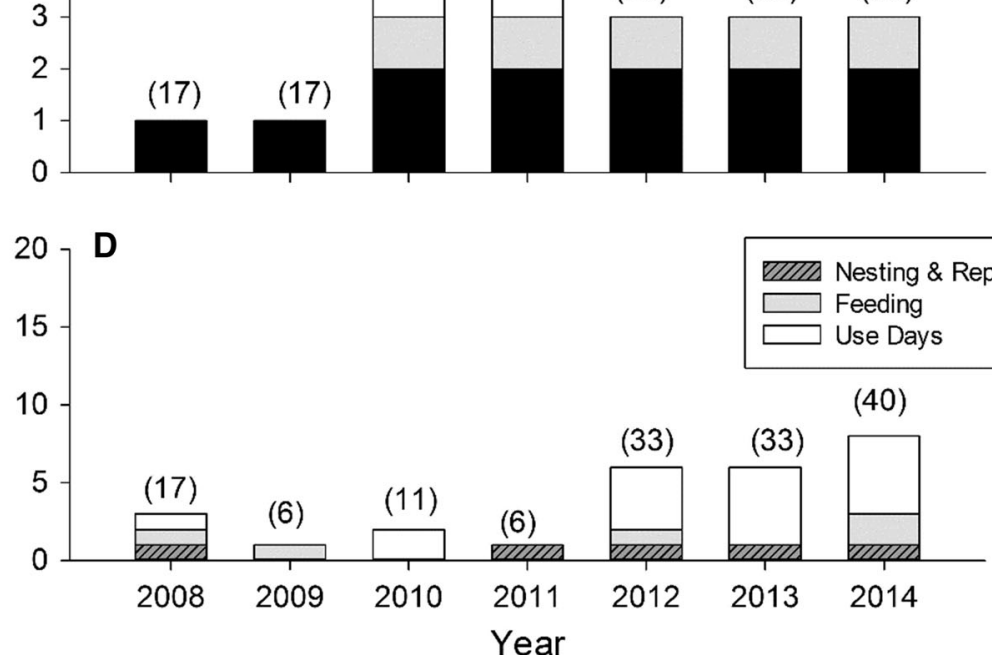

biomass in 2009 to $20.4 \%$ in 2014 (VanMiddlesworth \& Casper, 2014, 2015).

Potential threats to aquatic vegetation at the site also include increasing abundances of common carp (Cyprinus carpio) beginning in 2009 (Sparks et al., 2016), despite pre-restoration eradication efforts that were conducted in 2007 to reduce existing populations. Common carp are well established throughout the Illinois River basin and have been linked to significant reductions in water quality and rooted aquatic vegetation that have had adverse effects on previous restoration efforts of backwater habitats (Bajer et al., 2009). Current estimates of carp biomass at Emiquon show that they remain below threshold levels reported by Bajer et al. (2009) in which they can severely damage the ecological integrity of shallow lake systems. As such, aquatic plant communities can continue to thrive at Emiquon and contribute to the 
Fig. 3 Monthly means $( \pm 1$ SE) of A Secchi transparency depths and B water levels from The Nature Conservancy's Emiquon Preserve in central Illinois, USA. Secchi transparency data were collected from three sites weekly (2008-2013) and biweekly (2014) by the University of Illinois, Springfield, Illinois. River water overtopped the preserve levees for approximately 6 days in late April, 2013, during the historic flood of the Illinois River
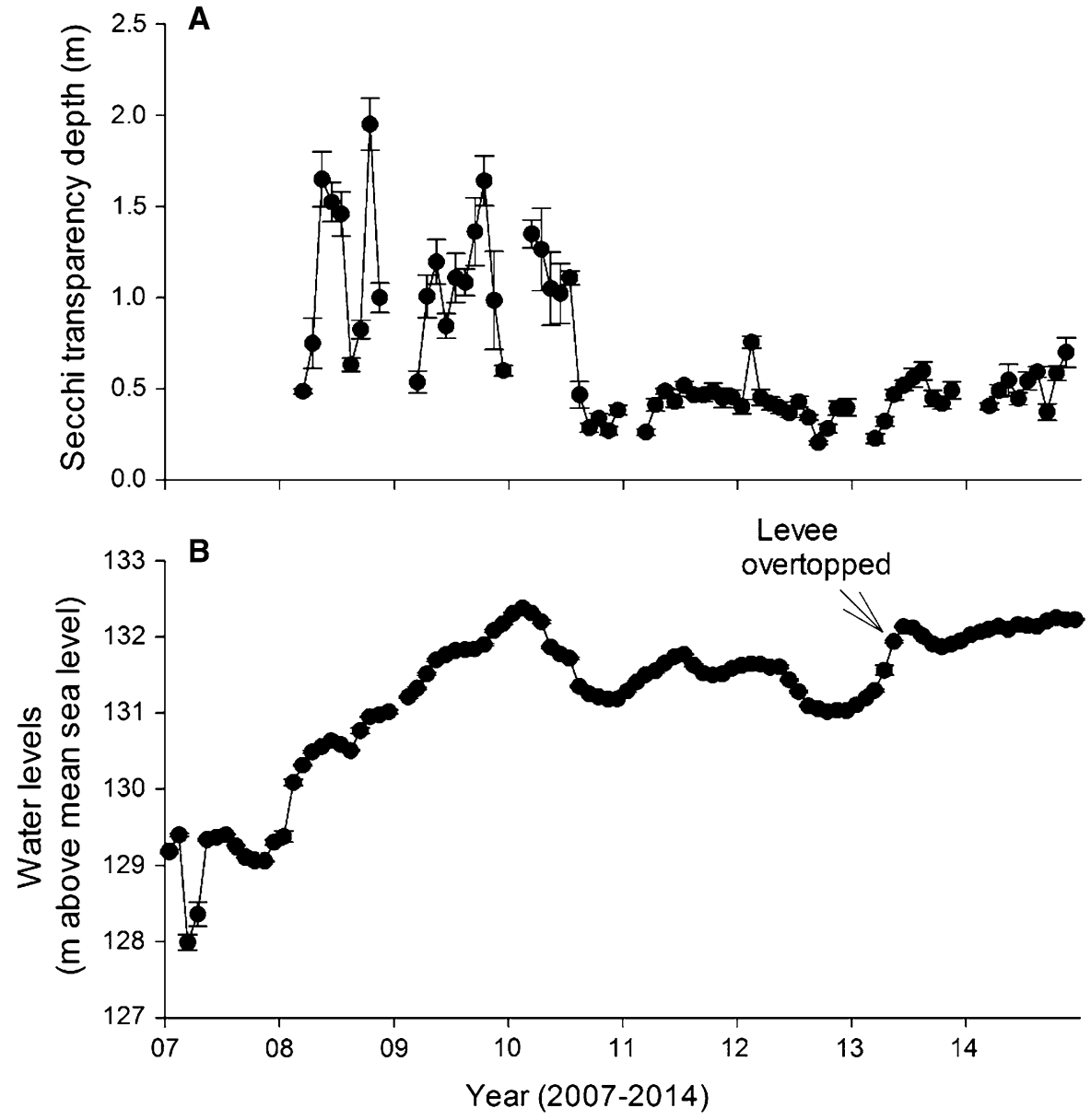

larger river system by providing critical vegetated backwater habitat that has largely been eliminated from the river floodplain (Bellrose et al., 1983; Stafford et al., 2010). Continued monitoring will provide timely updates on the extent to which carp approach potentially destructive thresholds that will inform future management recommendations (Sparks et al., 2016) that balance control of carp with other target requirements at the Preserve.

\section{Waterfowl}

Reinundation supported waterfowl targets during the early restoration stages, with 61 to $72 \%$ of indicators within acceptable ranges (Fig. 1E); however, a shift occurred between 2011 and 2012 in which indicators within acceptable ranges dropped from 67 to $44 \%$, primarily related to changes in DUDs and feeding (Fig. 2D). Several environmental changes may have contributed to this change in status, including a decline below acceptable ranges of hemi-marsh habitat used for waterfowl nesting and record water depths at the site after the 2013 flood (Fig. 3B) that likely reduced waterfowl fall foraging habitats and spring nesting sites (Hine et al., 2015). Environmental changes at Emiquon were reflected in brood count reductions below acceptable ranges in 2013 and 2014 (Hine et al., 2015).

Alignment of Emiquon waterfowl indicators with those of the Illinois River basin increased our ability to assess restoration status at the site level in context with annual variability patterns. Waterfowl use days for the first few years (2008-2011) were 17-132\% higher at Emiquon than the top five waterfowl lakes in the adjacent river reach; however, data showed a 10-50\% decline in DUDs at Emiquon compared to adjacent sites between 2012 and 2014 (Hine et al., 2015). These results support assessments that site-level changes 
were partially responsible for reduced fall migratory use at Emiquon and provide insight into the potential impacts of future water management decisions. Diving duck use days at Emiquon did not fall within desired ranges during most years; however, they were higher at the Preserve than nearby waterfowl lakes 5 out of 8 years (Hine et al., 2015). Migratory diving duck numbers have dramatically declined in the basin since the 1950s as backwater lakes and wetlands along the river have been degraded or drained for agricultural and urban uses (Havera, 1999); however, site-level monitoring data showed increased use of Emiquon by diving duck species including the lesser scaup (Aythya affinis), which is a species of conservation concern in Illinois (IDNR, 2005). Collectively, these data support the argument that restoration and management of backwater habitats, such as the Emiquon Preserve, can provide critically important habitat for migratory waterfowl along the Mississippi River flyway.

\section{Application for management and science}

Parrish et al. (2003) present a decision tree for rating the status of conservation targets that assesses the extent of intervention required to either restore or maintain all attributes within acceptable ranges of variation. It was recognized from the beginning that a major intervention of reconnecting Emiquon to the Illinois River would be required before restoration could ever be considered successful. After many years of planning, a water control structure was completed in 2016 that will once again provide connectivity between the Emiquon floodplain and the river that can be managed to balance ecological requirements of riverine targets with potential negative impacts of increased hydrologic alteration, riverine sediments, nutrients, and invasive species (Sparks et al., 2016). Water management capacity represents a critical intervention that will provide the potential to improve conservation status of floodplain and riverine targets that depend on water level fluctuations and river connectivity.

It is important to recognize that not all management strategies will benefit every target similarly and that inherent tradeoffs will exist that enhance the status of certain targets at the expense of others in any given year. For instance, spring drawdowns to support $B$. decurrens establishment and provide mudflat feeding habitats for shorebirds may reduce waterfowl feeding and nesting habitats during the spring of that year. The strength of using the KEA framework is that it provides real-time, comprehensive assessments of target responses to environmental conditions that will integrate and align future management actions with conservation goals. Application of this framework during the first 8 years of restoration revealed the annual variability of indicator status for conservation targets that would be expected in similar dynamic floodplain systems, further illustrating that all attributes for every target cannot be expected to achieve acceptable ranges in any given year. Future assessments of target- and site-scale status may be more realistic if measured over a multi-year period, especially as related to future water management application. Ultimately, a coordinated management effort among the collective sites within the larger 5729-ha Emiquon Complex would provide diverse habitat conditions to support many conservation targets in any given year at the complex level. Measurements of target status across these sites would thus provide a comprehensive assessment of the status of the larger Illinois River floodplain system.

At the site level, integration of a KEA framework early in restoration planning provided a systematic approach for setting conservation objectives and assessment measures for the Emiquon Preserve. Because data were limited regarding the attributes, indicators, and their acceptable ranges of variation specific to Emiquon conservation targets, initial development of these measures was based in large part on inputs and expertise of area scientists and land managers. As Parrish et al. (2003) point out, knowledge of conservation targets and specific data for rating their status will likely be limited in many situations. Incorporation of expert input into a restoration assessment framework for Emiquon created the structure on which to base a monitoring program focused on collecting data specific to conservation target attributes and their proposed acceptable ranges. This systematic approach of prioritizing monitoring efforts and reporting results annually provided quantitative data in a timely manner on which subsequent refinement of certain indicators and acceptable ranges could be substantiated. Quantitative data were also used to inform management on the progression of invasive species that could threaten conservation status. While aquatic invasives remain problematic, 
small populations of non-indigenous purple loosestrife (Lythrum salicaria) continue to be documented and removed from the site.

Alignment of the KEAs and indicator ranges with long-term monitoring provided significant insight into the roles of water level management and river connectivity for migratory waterfowl and fishes related to backwater habitat restorations. This status assessment represents the time period prior to river reconnection and provides an important baseline for development and testing of hypotheses pertaining to ecological responses of these targets to future water management and riverine connectivity. Results from these surveys will subsequently be incorporated into future management decisions as our capacity to manage water levels at the site is realized. We can use these 8 years of ecosystem data to develop working hypotheses on the effects of connectivity (e.g., water level management, nutrients, sediments) on conservation targets that can be tested and integrated back into a formalized adaptive management plan that includes continued input from scientist, managers, and stakeholders. As such, possible additions to KEAs might include eutrophication parameters (nutrients, chlorophyll $a$ ) as a measure that is incorporated into conservation assessments.

This study evaluated ecological outcomes to date for the restoration efforts at the Emiquon Preserve; however, a parallel approach with indicators and desired ranges could be applied to socioeconomic attributes to provide a more comprehensive evaluation of restoration success. For example, visitor use at the site may be a useful metric related to increased awareness or support for this and other similar projects. Indeed, some of the defined KEA and indicator ranges for the Preserve are not strictly linked to viability of conservation targets and are somewhat subjective, informed by historic and contemporary references that reflect social values. Even though fish species richness did not fall within the desired rating of $\geq 25$ native species in any given year (VanMiddlesworth \& Casper, 2014, 2015; VanMiddlesworth et al., 2014), the fish community was certainly viable as richness increased from 7 to 20 native species during the study period. Greater waterfowl use days are desirable to wildlife viewers and hunters, but use days less than the target range does not necessarily mean waterfowl will cease to use the site. A high catch-per-unit-effort of largemouth bass was established as an indicator of fish community composition, based on the hypothesis that high densities of this native predatory fish would achieve biological suppression of non-native invasive common carp. Although subsequent studies failed to support this hypothesis (VanMiddlesworth et al., 2016), the indicator was retained during the 2012 revision because it was a useful metric of a valuable sport fishery at the Preserve. Socioeconomic attributes have not been included in most analyses of restoration success (e.g., Wortley et al., 2013) and future revisions of the KEA framework at the Preserve will likely include measures of ecosystem services and related attributes.

\section{Summary}

Application of the KEA framework provided strategic and systematic monitoring data that resulted in consistent and timely assessments of trending patterns for focal conservation targets at the Emiquon Preserve. However, restoration is not yet a success, defined by Parrish et al. (2003), as conservation targets are conserved only when all attributes are within acceptable ranges of variation. Conservation efforts to date are just the initial steps toward restoration of ecological integrity at the site with the next step being utilization of a managed connection between the Preserve and the Illinois River. Our ability to manipulate water levels will provide new management options for controlling invasive species, maintaining hemi-marsh conditions, improving waterfowl and shorebird nesting and feeding habitats, and creating passage for riverine fishes to high-quality backwater habitat. As such, water management capacity is expected to increase overall ecological integrity of the Emiquon Preserve by providing the system with the ability to support and maintain biodiversity, aquatic plant communities, and ecosystem function. Continued review and modification of the KEA model in conjunction with a strategic monitoring program will provide critical information to guide relevant management decisions and testable hypotheses to reduce potential threats and achieve future restoration goals. This will inform management of future floodplain restoration and reconnection projects, thus meeting the overarching goal established during the early planning process to provide a foundation for 
future restoration investments in the larger Illinois and Upper Mississippi River valleys.

Acknowledgements The Nature Conservancy gratefully acknowledges all those who participated in the Emiquon Science Advisory Council meetings to develop the Key Ecological Attributes and indicators for the Emiquon Preserve. The Conservancy extends thanks to the Brinson Foundation, Illinois Tool Works Inc., the Legacy Fund, Lumpkin Family Foundation, Daniel F. and Ada L. Rice Foundation, Caterpillar Foundation, and others who supported the intense research and collaboration involved for development and monitoring of the Emiquon Preserve KEAs. Stuart Halse and an anonymous reviewer provided very constructive comments that greatly improved this manuscript. We thank M. J. Lemke and K. E. Dungey, University of Illinois at Springfield, for permission to include Secchi data from the Emiquon Preserve.

Open Access This article is distributed under the terms of the Creative Commons Attribution 4.0 International License (http:// creativecommons.org/licenses/by/4.0/), which permits unrestricted use, distribution, and reproduction in any medium, provided you give appropriate credit to the original author(s) and the source, provide a link to the Creative Commons license, and indicate if changes were made.

\section{References}

Ahn, C., R. E. Sparks \& D. C. White, 2004. A dynamic model to predict responses of millets (Echinocloa sp.) to different hydrologic conditions for the Illinois floodplain-River. River Research and Applications 20: 485-498.

Bajer, P. G., G. Sullivan \& P. W. Sorensen, 2009. Effects of a rapidly increasing population of common carp on vegetative cover and waterfowl in a recently restored Midwestern shallow lake. Hydrobiologia 632: 235-245.

Bellrose, F. C., S. P. Havera, F. L. Paveglio, Jr. \& D. W. Steffeck, 1983. The fate of lakes in the Illinois River Valley. Illinois Natural History Survey Biological Notes 119.

Christensen, N. L., A. M. Bartuska, J. H. Brown, S. Carpenter, C. D’Antonio, R. Francis, J. F. Franklin, J. A. MacMahon, R. F. Noss, D. J. Parsons, C. H. Peterson, M. G. Turner \& R. G. Woodmansee, 1996. The report of the Ecological Society of America Committee on the Scientific Basis for Ecosystem Management. Ecological Applications 6: 665-691.

Dale, V. H. \& S. C. Beyeler, 2001. Challenges in the development and use of ecological indicators. Ecological Indicators 1: 3-10.

Davies, P. E., J. H. Harris, T. J. Hillman \& K. F. Walker, 2010. The sustainable rivers audit: assessing river ecosystem health in the Murray-Darling Basin, Australia. Marine and Freshwater Research 61: 764-777.

Demissie, M., A. Wehrmann, Y. Lian, G. Amenu, S. Burch \& W. Bogner, 2005. Hydrologic and hydraulic considerations for the ecological restoration of the Emiquon along the Illinois River. Impacts of Global Change. doi:10.1061/ 40792(173)586.
Dynesius, M. \& C. Nilsson, 1994. Fragmentation and flow regulation of river systems in the northern third of the world. Science 266: 753-762.

Forbes, S. A. \& R. E. Richardson, 1913. Studies on the biology of the upper Illinois River. Bulletin of the Illinois State Laboratory of Natural History 9(10): 481-574.

Gore, J. A. \& F. D. Shields, 1995. Can large rivers be restored? BioScience 45: 142-152.

Hagy, H., C. Hine, M. Horath, A. Yetter, R. Smith \& J. Stafford, 2016. Waterbirds as indicators of floodplain restoration. Hydrobiologia. doi:10.1007/s10750-016-3004-3.

Hart, C. A., 1896. On the entomology of the Illinois River and adjacent waters. Bulletin of the Illinois State Laboratory of Natural History 4(6): 1-273.

Havera, S. P., 1999. Waterfowl of Illinois: status and management. Illinois Natural History Survey Special Publication 21.

Havera, S. P., K. E. Roat, \& L. L. Anderson, 2003. The Thompson Lake/Emiquon story: the biology, drainage, and restoration of an Illinois River bottomland lake. Illinois Natural History Survey Special Publication 25.

Hempel, A., 1898. A list of the protozoa and rotifers found in the Illinois River and adjacent lakes at Havana, Illinois. Bulletin of the Illinois State Laboratory of Natural History 5(6): 301-388.

Hine, C. S., H. M. Hagy, A. P. Yetter \& M. M. Horath, 2014. Waterbird and Wetland Monitoring at the Emiquon Preserve: Annual Report 2013. Illinois Natural History Survey Technical Report 2014 (18). 25 June 2014.

Hine, C.S., H.M. Hagy, A.P. Yetter, M.M. Horath \& J. M. Osborn, 2015. Waterbird and Wetland Monitoring at the Emiquon Preserve: Annual Report 2014. Illinois Natural History Survey Technical Report 2015 (21). 3 September 2015.

Hine, C. S., H. M. Hagy, M. M. Horath, A. P. Yetter, R. V. Smith \& J. D. Stafford, 2016. Response of aquatic vegetation communities and other wetland cover types to floodplain restoration at Emiquon Preserve. Hydrobiologia. doi:10. 1007/s10750-016-2893-5.

Holling, C. S. \& G. K. Meffe, 1996. Command and control and the pathology of natural resource management. Conservation Biology 10: 328-337.

Illinois Department of Natural Resources (IDNR), 2005. The Illinois Comprehensive Wildlife Conservation Plan \& Strategy. Illinois Department of Natural Resources, Springfield [available on internet at http://www.dnr. illinois.gov/conservation/IWAP/Documents/ WildlifeActionPlanFinal.pdf]. Accessed 21 January 2016.

Jungwirth, J., S. Muhar \& S. Schmutz, 2002. Re-establishing and assessing ecological integrity in riverine landscapes. Freshwater Biology 47: 867-887.

Koebel Jr., J. W., 1995. An historical perspective on the Kissimmee River restoration project. Restoration Ecology 3: 149-159.

Kofoid, C. A., 1903. Plankton studies. IV. The plankton of the Illinois River, 1894-1899, with introductory notes upon the hydrography of the Illinois River and its basin. Part I. Quantitative investigations and general results. Bulletin of the Illinois State Laboratory of Natural History 6(2): 95-629.

Lamouroux, N., J. A. Gore, F. Lepori \& B. Statzner, 2015. The ecological restoration of large rivers needs science-based, 
predictive tools meeting public expectations: an overview of the Rhône project. Freshwater Biology 60: 1069-1084.

Mettler-Cherry P. A. \& M. Smith, 2009. The history of the Illinois River and the decline of a native species. The Confluence (Fall 2009): 34-45.

Michaels, N. N. \& G. G Sass, 2009. The Nature Conservancy's Emiquon Preserve fish and aquatic vegetation monitoring annual report (2008). Illinois Natural History Survey Illinois River Biological Station, Havana.

Noss, R. F., 1990. Indicators for monitoring biodiversity: a hierarchical approach. Conservation Biology 4: 355-364.

National Research Council (NRC), 1992. Restoration of Aquatic Ecosystems: Science, Technology, and Public Policy. National Academy Press, Washington, D.C.

Page, L. M. \& B. M. Burr, 1991. A Field Guide to Freshwater Fishes North of Mexico. Houghton Mifflin Co., Boston.

Palmer, M. A., K. L. Hondula \& B. J. Koch, 2014. Ecological restoration of streams and rivers: shifting strategies and shifting goals. The Annual Review of Ecology, Evolution, and Systematics 45: 247-269.

Parrish, J. D., D. P. Braun \& R. S. Unnasch, 2003. Are we conserving what we say we are? Measuring ecological integrity within protected areas. BioScience 53: 851-860.

Poff, N. L., J. D. Allan, M. B. Bain, J. R. Karr, K. L. Prestegaard, B. D. Richter, R. E. Sparks \& J. C. Stromberg, 1997. The natural flow regime. BioScience 47: 769-784.

Ramsar, 2014. The list of wetlands of international importance [available on internet at http://ramsar.rgis.ch/pdf/sitelist.pdf].

Rogers, K. \& H. Biggs, 1999. Integrating indicators, endpoints and value systems in strategic management of the rivers of the Kruger National Park. Freshwater Biology 41: 439-451.

Rogers, K., 2006. The real river management challenge: integrating scientists, stakeholders and service agencies. River Research and Applications 22: 269-280.

Roux, D. J., K. H. Rogers, H. C. Biggs, P. J. Ashton, \& A. Sergeant. 2006. Bridging the science-management divide: Moving from unidirectional knowledge transfer to knowledge interfacing and sharing. Ecology and Society 11: 4 [available on internet at http://www.ecologyand societ.org/vol11/iss1/art4/].

Sparks, R. E., 1995. Need for ecosystem management of large rivers and their floodplains. BioScience 45: 168-182.

Sparks, R. E., J. C. Nelson \& Y. Yin, 1998. Naturalization of the flood regime in regulated rivers. BioScience 48: 706-720.

Sparks, R. E., K. D. Blodgett, A. F. Casper, H. M. Hagy, M. J. Lemke, L. F. M. Velho \& L. C. Rodrigues, 2016. Why experiment with success? Opportunities and risks in applying assessment and adaptive management to the Emiquon floodplain restoration project. Hydrobiologia. doi:10.1007/s10750-016-2785-8.

Stafford, J. D., M. M. Horath, A. P. Yetter, R. V. Smith \& C. S. Hine, 2010. Historical and contemporary characteristics and waterfowl use of Illinois River valley wetlands. Wetlands 30: 565-576.

The Nature Conservancy (TNC), 1998. Illinois River Site Conservation Plan. The Nature Conservancy, Peoria.

The Nature Conservancy (TNC), 2000. Conservation in a highly fragmented landscape: the central tallgrass prairie ecoregional plan.
The Nature Conservancy (TNC), 2006. Key attributes and indicators for Illinois river conservation targets at The Nature Conservancy's Emiquon Preserve. The Nature Conservancy, Peoria, Illinois [available on internet at www.uis.edu/emiquon/wp-content/uploads/sites/78/2013/ 04/KEA_Report_and_Analysis.pdf]. Accessed November 7, 2015 .

Tockner, K. \& J. A. Stanford, 2002. Review of: Riverine flood plains: Present state and future trends. Biological Sciences Faculty Publications. Paper 166 [available on internet at http://scholarworks.umt.edu/biosci_pubs/166].

Thompson, J., 2002. Wetlands Drainage, River Modification, and Sectoral Conflict in the Lower Illinois Valley, 1890-1930. Southern Illinois University Press, Carbondale.

UMRCC, 2000. A river that works and a working river: A strategy for the natural resources of the Upper Mississippi River system. Upper Mississippi River Committee, Rock Island [available on internet at http://www.umrcc.org/ Reports/Publications/A\%20River\%20That\%20works\% 20(Condensed).pdf]. Accessed 1 July 2016.

U.S. Army Corps of Engineers. 2007. Illinois River Basin Restoration Comprehensive Plan with Integrated Environmental Assessment [available on internet at http://www. mvr.usace.army.mil/Portals/48/docs/Environmental/ILRBR/ CompPlan/MAIN\%20REPORT\%20and\%

20APPENDICES\%20-\%20CD.pdf]. Accessed 1 July 2016.

U.S. Geological Survey (USGS), 2015. Long-term resource monitoring: an element of the Upper Mississippi River Restoration Program [available on internet at http://www. umesc.usgs.gov/ltrmp.html]. Accessed 21 January, 2016.

VanMiddlesworth, T. D. \& A. F. Casper, 2014. The Nature Conservancy's Emiquon Preserve Fish and Aquatic Vegetation Monitoring Annual Report (2013). Illinois Natural History Survey Illinois River Biological Station, Havana.

VanMiddlesworth, T. D. \& A. F. Casper, 2015. The Nature Conservancy's Emiquon Preserve Fish and Aquatic Vegetation Monitoring Annual Report (2014). Illinois Natural History Survey Illinois River Biological Station, Havana.

VanMiddlesworth, T. D., N. N. Michaels \& A. F. Casper, 2014. The Nature Conservancy's Emiquon Preserve Fish and Aquatic Vegetation Monitoring 6-Year (2007-2012) Report. Illinois Natural History Survey, Illinois River Biological Station, Havana.

VanMiddlesworth, T. D., N. N. McClelland, G. G. Sass, A. F. Casper, T. W. Spier \& M. J. Lemke, 2016. Fish community succession and biomanipulation to control two common aquatic ecosystem stressors during a large-scale floodplain lake restoration. Hydrobiologia. doi:10.1007/ s10750-016-2696-8.

Weitzell, R. E., M. L. Khoury, P. Gagnon, B. Schreurs, D. Grossman \& J. Higgins, 2003. Conservation Priorities for Freshwater Biodiversity in the Upper Mississippi River Basin. Nature Serve and The Nature Conservancy, Arlington: 89.

Wortley, L., J. Hero \& M. Howes, 2013. Evaluating ecological restoration success: a review of the literature. Restoration Ecology 21: 537-543. 